\title{
Chronic kidney disease after liver, cardiac, lung, heart-lung, and hematopoietic stem cell transplant
}

\author{
Sangeeta Hingorani
}

Received: 15 August 2007 /Revised: 30 January 2008/Accepted: 31 January 2008/Published online: 15 April 2008

(C) IPNA 2008

\begin{abstract}
Patient survival after cardiac, liver, and hematopoietic stem cell transplant (HSCT) is improving; however, this survival is limited by substantial pretransplant and treatmentrelated toxicities. A major cause of morbidity and mortality after transplant is chronic kidney disease (CKD). Although the majority of CKD after transplant is attributed to the use of calcineurin inhibitors, various other conditions such as thrombotic microangiopathy, nephrotic syndrome, and focal segmental glomerulosclerosis have been described. Though the immunosuppression used for each of the transplant types, cardiac, liver and HSCT is similar, the risk factors for developing CKD and the CKD severity described in patients after transplant vary. As the indications for transplant and the long-term survival improves for these children, so will the burden of CKD. Nephrologists should be involved early in the pretransplant workup of these patients. Transplant physicians and nephrologists will need to work together to identify those patients at risk of developing CKD early to prevent its development and progression to end-stage renal disease.
\end{abstract}

Keywords Chronic kidney disease - Liver transplant . Cardiac transplant $\cdot$ Hematopoietic stem cell transplant . Calcineurin inhibitors · Risk factors · Epidemiology · Lung transplant

\section{Introduction}

Chronic kidney disease (CKD) is a frequent and increasingly recognized complication of solid-organ and hemato-

\section{S. Hingorani $(\bowtie)$}

Pediatrics-University of Washington,

4800 Sandpoint Way NE M1-5,

Seattle, WA 98015, USA

e-mail: sangeeta.hingorani@seattlechildrens.org poietic stem cell transplantation (HSCT), increasing the complexity of patient management and impacting survival. The incidence of CKD after cardiac, liver, and HSCT varies from $7-86 \%$ in pediatric patients, partly due to the lack of a uniform definition of CKD after transplant (Table 1). Up to $16 \%$ of transplant survivors will develop end-stage renal disease (ESRD) [1-19].

This review focuses on the epidemiology, risk factors, and outcomes of children who develop CKD after liver, cardiac, lung, heart-lung, and stem cell transplant.

\section{Liver transplant}

\section{Epidemiology}

The majority of studies of renal disease after liver transplantation has been done in adults, and the cumulative incidence of CKD varies from $5 \%$ to $30 \%$ over $1-5$ years after transplant [20]. In a retrospective study of 117 pediatric liver transplant patients who survived 3 years after transplant (median 7.6, range 3-14.6 years), the prevalence of $\mathrm{CKD}$, defined as a glomerular filtration rate (GFR) $<70 \mathrm{ml} / \mathrm{min}$ per $1.73 \mathrm{~m}^{2}$ at last follow-up was $32 \%$ [1]. In a 10-year follow-up study of 12 children undergoing a liver transplant in France, mild to moderate CKD (mild = GFR $60-80 \mathrm{ml} / \mathrm{min}$ per $1.73 \mathrm{~m}^{2}$; moderate $=$ GFR $20-60 \mathrm{ml} / \mathrm{min}$ per $1.73 \mathrm{~m}^{2}$ ) developed in six of seven patients. Early deterioration of renal function is usually seen within the first year following transplant, followed by a period of stabilization, then with progression on long-term follow-up [2, 3]. In contrast, in a study of 50 pediatric liver transplant patients in Poland, CKD stages 2 and 3 as defined by the National Kidney Foundation Kidney Disease Outcomes Quality Initiative (NKF/KDOQI) (Table 2) developed at 1 year after transplant and remained stable after 3 years of follow-up [4]. In this study, GFR was calculated 
Table 1 Percentage of patients with chronic kidney disease (CKD) and end-stage renal disease (ESRD) based on transplant type

\begin{tabular}{lcll}
\hline Transplant type & CKD & ESRD & Reference \\
\hline Liver & $28-86 \%$ & $0-8 \%$ & {$[1-5]$} \\
Cardiac & $7-54 \%$ & $2 \%$ & {$[6-10]$} \\
Heart-lung & $34 \%$ & $7-16 \%$ & {$[11-13]$} \\
Hematopoietic stem & $18-42 \%$ & $5-8 \%$ & {$[14-19]$} \\
cell transplantation & & & \\
\hline
\end{tabular}

using both diethylenetriamine pentaacetic acid (DTPA) plasma clearance and estimated using the Schwartz formula. Little correlation was found between the two methods with the Schwartz formula, consistently overestimating GFR [4]. Therefore, the prevalence of CKD is likely underestimated in this patient population if estimated measures of GFR or serum creatinine are used to define CKD.

\section{Risk factors for developing CKD}

Many patients will have renal disease at the time of liver transplant secondary to hepatorenal syndrome and/or acute tubular necrosis. In one study, renal histology pretransplant revealed glomerulosclerosis and other mild glomerular changes with mesangial matrix expansion, capillary-wall changes, and mesangial immunoglobulin (Ig) G, IgA, and $\operatorname{IgM}$ in the majority of cases despite normal serum creatinines [21]. Ultrasonographic findings included nephromegaly and increased echogenicity, which improved in the majority of cases after transplant [22]. In pediatric patients, there can be renal involvement from the primary liver disease, as in patients with primary hyperoxaluria, autosomal recessive polycystic kidney disease, Alagille's syndrome, and tyrosinemia (Table 3). Renal dysfunction in patients with these disorders often improves after liver transplant. However, the long-term affects of preexisting renal disease on developing CKD after orthotopic liver transplant has not been studied systematically in pediatric patients. In contrast, in adult liver transplant patients who develop acute renal failure during the peri- and postoper-

Table 2 National Kidney Foundation Kidney Disease Outcomes Quality Initiative definition of chronic kidney disease by stage

\begin{tabular}{lll}
\hline Stage & Description & eGFR $\left(\mathrm{ml} / \mathrm{min}\right.$ per $\left.1.73 \mathrm{~m}^{2}\right)$ \\
\hline 1 & $\begin{array}{c}\text { Kidney damage with } \\
\text { normal or } \uparrow \text { GFR }\end{array}$ & $\geq 90$ \\
2 & Kidney damage with & $60-89$ \\
& mild $\downarrow$ GFR & $30-59$ \\
3 & Moderate $\downarrow$ GFR & $15-29$ \\
4 & Severe $\downarrow$ GFR & $<15$ or dialysis \\
5 & Kidney failure &
\end{tabular}

$e G F R$ estimated glomerular filtration rate
Table 3 Liver diseases associated with preexisting renal disease

Tyrosinemia
Autosomal recessive polycystic kidney disease
Alagille's syndrome
Primary hyperoxaluria
Hepatitis B- and C-related glomerulonephritis

ative periods, there is an increased risk for developing CKD after transplant [23] and progression to CKD stage 5 requiring dialysis [24].

Other identified risk factors (Table 4) for CKD include GFR $<70 \mathrm{ml} / \mathrm{min}$ per $1.73 \mathrm{~m}^{2}$ at 1 year after transplant and cyclosporine use [1]. In this study, there was an inverse relationship between hypertension at 1 year after transplant and development of renal dysfunction. In addition, in adult patients, preexisting diabetes, pre- and postoperative renal failure, hypertension, age, female gender, and hepatitis $\mathrm{C}$ infection increased the risk of CKD and ESRD [20]. Though the majority of renal dysfunction after liver transplant is attributed to the use of cyclosporine and/or tacrolimus, there have been reports of other types of pathology present leading to CKD. Studies have found preexisting renal disease such as focal segmental glomerulosclerosis (FSGS) and hepatitis-Crelated injury including membranoproliferative glomerulone-

Table 4 Risk factors for developing chronic kidney disease by type of transplant

\section{Risk factor common to all transplant types}

Calcineurin inhibitor use

Liver

GFR of $<70 \mathrm{ml} / \mathrm{min}$ per $1.73 \mathrm{~m}^{2}$ at 1 year after transplant

Pretransplant renal dysfunction

Acute renal failure

Preexisting diabetes

Age

Female gender

Hepatitis C

\section{Cardiac}

Pretransplant dialysis

Hypertrophic cardiomyopathy

African American race

Previous transplant

Pretransplant diabetes

Extracorporeal membrane oxygenation use

\section{Heart-lung}

Hypertension posttransplant

Elevated serum creatinine at 1 month posttransplant

Hematopoietic stem cell transplant

Acute graft-versus-host disease grades II-IV

Older age

Transplant from an unrelated donor

Acute renal failure

Chronic graft vs. host disease

Total body irradiation 
phritis, unresolved hepatorenal syndrome, and diabetic nephropathy on renal biopsy after liver transplant $[25,26]$.

\section{Calcineurin inhibitors}

The use of cyclosporine (CSA) and tacrolimus in managing liver transplant patients has greatly improved outcomes. However, the improvement in survival is associated with an increased development of CKD. The manifestations of CSA toxicity range from asymptomatic azotemia and proteinuria to fulminant multiorgan failure [27]. In addition to the commonly described striped fibrosis and arterial and vascular lesions seen in patients on these medications, thrombotic microangiopathy has also been described in as many as $50 \%$ of patients after liver transplant [25]. These lesions are typically characterized by mesangiolysis, thrombus formation within glomerular capillaries, and widening of the subendothelial spaces. The nephrotoxic effects of CSA correlate with drug serum levels and therapy duration. CSA is also known to cause arteriolar injury, glomerulosclerosis, and interstitial fibrosis, as well as diffuse expansion of the mesangial matrix [28, 29]. The hypothesized mechanisms behind this injury appears to be vasoconstriction secondary to an imbalance between the vasodilatory hormones such as prostaglandin E1 and vasoconstrictive ones such as thromboxane A2 [30]. Increased synthesis of transforming growth factor (TGF)$\beta 1$ by calcineurin inhibitors also contributes to the development of CKD in patients after transplant, and genetic polymorphisms in the TGF- $\beta 1$ gene have been associated with the development of ESRD after cardiac transplant [31].

Reducing calcineurin inhibitor levels while adding mycophenolate mofetil (MMF) in patients with CKD 5 years after liver transplant resulted in renal function improvements as measured by serum creatinine and creatinine clearance after 24 months of combined therapy, with only minor changes noted in immune function in these patients. Decreases in microalbuminuria were also noted [32]. Some authors have suggested that thrice-daily dosing of cyclosporine leads to decreased nephrotoxicity and only mild histopathologic changes in the kidney after 3 years of follow-up [33]. The authors attribute their findings to more constant trough blood levels and lower, less toxic, peak levels as well as the use of a calcium-channel blockers to manage their patients' hypertension [33]. In a case series, three children who underwent combined liver and kidney transplant were switched to sirolimus because of prolonged renal failure requiring dialysis and acute calcineurin inhibitor toxicity on biopsy. All three demonstrated improved renal function with cessation of dialysis [34]. These studies suggest that decreasing calcineurin inhibitor exposure by adding MMF or eliminating long-term exposure by switching to sirolimus can have beneficial effects on renal function in children after liver transplantation.

\section{Cardiac transplantation}

\section{Epidemiology}

Approximately 350 pediatric cardiac transplants are performed annually in the USA [7]. In a 2006 report from the International Society for Heart and Lung Transplantation, the incidence of renal dysfunction (defined as an abnormal serum creatinine) was $10 \%$ at 5 years after cardiac transplant [6]. Sixty-three percent of patients had hypertension. After 8 years of follow-up, the percentage of patient with renal dysfunction did not change, but $2 \%$ of patients were on dialysis or had received a renal transplant. In reports from single centers, the incidence of CKD at approximately 10 years after cardiac transplant in pediatric patients ranged from $7 \%$ to $54 \%$; however, only a small percentage of these patients progress to ESRD requiring dialysis and/or renal transplantation [7-10]. Hypertension is a more common finding, occurring in approximately $70 \%$ of patients after transplant [7-10]. Some centers actually report an improvement in kidney function in the first year following cardiac transplant and stabilization thereafter [9]. In adult studies, there is an increased risk of mortality associated with development of CKD [35, 36].

\section{Risk factors for development of CKD after cardiac} transplant

A recent study of 2,032 pediatric cardiac transplant patients transplanted between 1990 and 1999 identified pretransplant dialysis, hypertrophic cardiomyopathy, African American race, and previous transplant as risk factors for developing CKD (defined in this study as a creatinine $>2.5 \mathrm{mg} / \mathrm{dl}$ ) [37]. Additional risk factors for developing ESRD included pretransplant diabetes and intensive care unit stay or extracorporeal membrane oxygenation [37]. In the adult population, several risk factors for CKD development have been identified and include older age at transplant, pretransplant serum creatinine, preexisting diabetes, abnormal GFR at 1 year after transplant, hypertension after transplant, and cyclosporine immunosuppression within the first 6 months after transplant [12, 35, 36, 38, 39]. Risk factors for progression to ESRD include postoperative development of hypertension and proteinuria of $>1 \mathrm{~g} / 24 \mathrm{~h}[13,40]$.

\section{Calcineurin inhibitors}

Though the nephrotoxic effects of calcineurin inhibitors are well known, data in the pediatric cardiac transplant 
population are conflicting. After 18 months of triple immunosuppression including cyclosporine, patients' GFR remained stable, and renal biopsy specimens in four patients did not show signs of cyclosporine toxicity [41]. Minor abnormalities in tubular function resulting in hyperuricemia and hyperkalemia were reported. Similarly, in a study of adult cardiac transplant patients treated with cyclosporine for 5 years, GFR (measured by inulin clearance) remained stable at $66 \mathrm{ml} / \mathrm{min}$ per $1.73 \mathrm{~m}^{2}$, as did tubular function. The only abnormalities noted were hypertension and the presence of microalbuminuria. However, other studies of pediatric cardiac transplant patients found an association between cyclosporine use within the first 2 months after transplant and decreases in GFR years after transplant [42]. High cyclosporine levels $(>500 \mu \mathrm{g} / \mathrm{L})$ in the first 6 months after cardiac transplant were associated with developing ESRD at anytime after cardiac transplant [43]. In a pediatric study of 14 patients with progressive decline in renal function over $2-5$ years, inulin clearance declined from $84 \mathrm{ml} / \mathrm{min}$ per $1.73 \mathrm{~m}^{2}$ at 1 year to $49.8 \mathrm{ml} /$ $\min$ per $1.73 \mathrm{~m}^{2}$ at 5 years. Biopsies performed on 13 patients revealed chronic tubulointerstitial lesions of grade II associated with acute changes of vacuolization of the proximal tubules. Arteriolar lesions were also present, along with focal glomerular scarring and fibrosis. Lesion extent correlated with calcineurin therapy duration. After reduction in calcineurin inhibitor dose by $50 \%$ and change from azathioprine to MMF, a $67 \%$ improvement in GFR $\left(77 \mathrm{ml} / \mathrm{min}\right.$ per $1.73 \mathrm{~m}^{2}$ ) was noted 1 year after the change. The authors suggest that this improvement may be related to a decrease in preglomerular vasoconstriction [44]. In a study of pediatric patients treated with tacrolimus after transplant, $41 \%$ of patients had elevations in serum creatinine of $1-2 \mathrm{mg} / \mathrm{dl}$ approximately $2-3$ years after transplant [45].

\section{Heart-lung and lung transplantation}

\section{Epidemiology}

The cumulative incidence of CKD, defined as a doubling of serum creatinine, after lung or heart-lung transplantation varies from $34 \%$ at 1 year after transplant to $53 \%$ by 5 years after transplant [11]. ESRD occurs in $7.3-16 \%$ of patients 5 years after transplant [11-13]. The majority of patients, $51 \%$, developed CKD stage 3 by 1 year posttransplant [12].

Risk factors for CKD after heart-lung and lung transplant

Risk factors identified for developing CKD in a study of 219 patients undergoing a lung or a heart-lung transplant include cumulative periods of a diastolic blood pressure
$>90 \mathrm{mmHg}$ and serum creatinine value at 1 month posttransplant [11]. In this same study, the authors found that tacrolimus use in the first 6 months posttransplant decreased the risk of CKD compared with those who received cyclosporine alone. Other studies found GFR at 1 month to be a predictor of later CKD [12]. Development of postoperative hypertension is associated with an increased risk of ESRD after lung and heart-lung transplants [13].

\section{Hematopoietic stem cell transplant}

\section{Epidemiology}

The cumulative incidence of CKD varies from $13 \%$ to $60 \%$ in adult studies [15-17] to as high as $62 \%$ in children [14]. CKD usually becomes apparent 6-12 months after HSCT, although it has been described as early as 2 months and as late as 10 years posttransplant. Though this section discusses injury that occurs after HSCT, baseline or pretransplant renal function can impact the results [46]. Therefore, baseline assessments not only of serum creatinine but also urinalyses and more formal estimations of GFR are warranted. Accurate assessment of baseline renal function can help guide later medication dosing.

There are three distinct clinical manifestations of renal disease that can occur in the HSCT patient: thrombotic microangiopathy (TMA), typically hemolytic uremic syndrome (HUS), graft-versus-host-disease (GVHD)-related $\mathrm{CKD}$, and nephrotic syndrome (NS). TMA syndromes represent a spectrum of clinical diseases characterized by systemic or intrarenal platelet aggregation, thrombocytopenia, and microvascular fragmentation of erythrocytes. Platelet aggregation can result in ischemia and organ injury. When renal injury is predominant, a diagnosis of HUS is usually rendered, whereas the presence of extensive extrarenal manifestations leads to a diagnosis of thrombotic thrombocytopenic purpura (TTP) (reviewed in [47]).

\section{Histopathology of TMA after HSCT}

Microscopic examination of kidney biopsy specimens from patients with TMA-associated CKD demonstrates mesangiolysis and loss of endothelial cells with expansion of the subendothelium and occlusion of capillary loops. On electron micrographs, there is extensive widening of the space between the glomerular basement membrane and the subendothelium, with amorphous deposits that are not immune complexes.

\section{Risk factors for HUS after HSCT}

Though no clear relationships have been found to date for the development of TMA after HSCT, a number of risk 
factors have been examined. In earlier studies, where HUS was the primary diagnosis, risk factors identified were total body irradiation (TBI) [14, 15, 48, 49] and calcineurin inhibitor use [15, 27, 50-54]. However, in more recent studies of TMA, acute graft-versus-host disease (GVHD) grades $2-4$, older age, and transplant from an unrelated donor are the primary risk factors identified $[55,56]$. Other investigators identified sinusoidal obstruction syndrome, matched unrelated donors or haploidentical donors, and lymphoid malignancy as significant predictors of TMA after HSCT in addition to the above risk factors [17, 5759]. However, in children who develop HUS after HSCT, the presumptive risk factor in these studies was TBI used as part of the conditioning regimen. For example, Tarbell et al. studied 44 children (aged 3-15 years) with acute lymphocytic leukemia (ALL) or neuroblastoma (NB) who underwent HSCT [14]. Twenty-nine of these patients were alive and in remission 3 months after HSCT and were evaluated in the study. Eleven patients developed increases in blood urea nitrogen (BUN) and creatinine, and ten were anemic and thrombocytopenic with evidence of hemolysis on peripheral blood smear; they also had elevated lactate dehydrogenase (LDH) levels. In every patient except one, the hemolytic process resolved, yet renal insufficiency persisted. The pathologic findings of mesangiolysis with intraglomerular capillary aneurysm formation in conjunction with laboratory abnormalities support the diagnosis of HUS in these children. In another small study, Antignac et al. described seven children referred to their nephrology clinic with CKD approximately 5-10 months after TBI followed by HSCT [48]. All seven children had leukemia, and all received cyclophosphamide alone or with cytosine arabinoside and vepeside, in addition to single-dose TBI as part of their conditioning regimen. Three patients developed CKD without hypertension, and four developed HUS with severe hypertension and microangiopathic hemolytic anemia. Of these, two of the four had normalization of their renal function. Follow-up biopsies, however, showed extensive scarring of the renal parenchyma but almost complete resolution of the mesangiolysis. The glomeruli were globally sclerotic, ischemic, or demonstrated mesangial hypercellularity. Thus, there was evidence of persistent and progressive renal damage in these patients despite normalization of serum creatinine and urinalysis. The occurrence of two different clinical presentations, CKD without hypertension and HUS with hypertension, but similar pathology in these children supports the notion that this is a spectrum of disease rather than distinct pathophysiologic processes.

\section{GVHD-related CKD}

GVHD-related CKD in this patient population is usually defined as an elevated serum creatinine or an abnormal
GFR 6-12 months after transplant. The incidence of GVHD-related CKD in children after HSCT varies from $11 \%$ to $41 \%$ [60-63]. In one recent study, the incidence of CKD (GFR $<70 \mathrm{ml} / \mathrm{min}$ per $1.73 \mathrm{~m}^{2}$ ) changed over time, with $41 \%$ of children having CKD at 1 year, $31 \%$ at 3 years, and only $11 \% 7$ years after transplant [63]. In approximately $19 \%$ of patients, hematuria and proteinuria persisted up to 10 years after HSCT. Berg and Bolme followed 44 children with acute lymphocytic leukemia (ALL), acute myeloblastic leukemia (AML), and severe aplastic anemia (SAA) and found a significant decrease in GFR 1-2 years after HSCT when compared with their baseline GFR (ALL and AML groups) or with a healthy control group despite serum creatinines that remained within normal limits. An initial decrease in GFR was followed by stabilization up to 5 years posttransplant [64]. This study supports the contention that serum creatinine is not an accurate measure of kidney function. Serum creatinine level and related estimating equations, routinely used clinical measures to estimate kidney function, are dependent on muscle mass and are influenced by age, race, gender, and weight $[65,66]$. Patients undergoing HSCT may have large fluctuations in their nutritional status, muscle mass, and weight that will influence GFR based on estimation equations or serum creatinine levels. Proximal tubular dysfunction has also been described in 14-45\% of pediatric patients 1-2 years after HSCT, with initial injury to the proximal tubules being nonspecific as reflected by elevated urinary excretion of alpha- 1 microglobulin and beta- $N$-acetylglucosaminidase ( $\beta$-NAG) followed by more specific damage manifested by decreases in phosphate reabsorption [67].

\section{Risk factors for GVHD-related CKD}

The risk factors for GVHD-related CKD in children are similar to those identified in adult studies. Kist-van Holthe et al. also retrospectively identified risk factors for developing both acute and chronic renal insufficiency in a cohort of 142 children undergoing transplant over a period of 5 years in the Netherlands [68]. All children received allogeneic transplants. Ninety-one children received radiation, and 82 of these 91 received TBI. Twenty-five children (18\%) had CKD (defined as a GFR $<85 \mathrm{ml} / \mathrm{min}$ per $1.73 \mathrm{~m}^{2}$ ). These authors found no correlation between radiation dose used and renal insufficiency at 1 year. In a later study from the same group, only acute renal insufficiency predicted the later development of CKD in patients after HSCT [62]. These studies contradict others in the literature that found TBI to be associated with renal injury $[60,61,69]$. However, the doses used here (5-8 Gy in a single fraction) were much lower than described elsewhere. In a study of 92 pediatric HSCT patients by van 
Why et al., late renal insufficiency developed in 18 of 64 (28\%) patients; in half of these patients, the renal disease persisted for 3 months to 3 years [60]. Amphotericin B use, cyclosporine, and TBI were associated with the later development of CKD. In a large retrospective review of 1,635 children and adults, risk factors for developing CKD after HSCT included acute renal failure and acute and chronic GVHD [17]. In this study, TBI was not associated with development of CKD.

\section{Nephrotic syndrome (NS) after HSCT}

Chronic GVHD may manifest itself in the kidney as NS with or without renal insufficiency (reviewed in [70]). Patients usually present with proteinuria, edema, and hypoalbuminemia. The majority of these case reports demonstrate membranous nephropathy (MN) with subepithelial deposits on biopsy; it is postulated that these deposits are antigen/antibody complexes representing GVHD in the kidney. However, cases of minimal-change disease (MCD), which is thought to be a T-cell-mediated process, have also been described [70]. Comparisons between case reports of MN and MCD after HSCT found that $\mathrm{MN}$ occurs in $61 \%$ of cases compared with $22 \%$ of cases having MCD [71]. The majority of reported patients with MN were slightly older males with a history of acute and chronic GVHD. Both MCD and MN occur later after transplant, at 8 and 14 months, respectively, and tend to occur within 1-5 months of GVHD development and/or the tapering of immunosuppression for their chronic GVHD. MN is more difficult to treat, with only $27 \%$ of patients reportedly achieving remission compared with $90 \%$ of patients with MCD [71]. Others have reported cases of diffuse proliferative glomerulonephritis, anti-nuclear-cytoplasmic-antibody (ANCA)-related glomerulonephritis, focal segmental glomerulosclerosis, and IgA nephropathy [72-76] occurring after HSCT. The development of each of these diseases seems to be associated with chronic GVHD and/or immunosuppression tapering. Treatment with high-dose prednisone and/or reinstitution of calcineurin inhibitors usually results in resolution of NS. Some physicians have used rituximab successfully in patients with NS after HSCT, typically in cases of MN [77].

\section{Management of CKD after liver, cardiac, lung, and HSCT}

Patients who develop CKD after liver, cardiac, lung, and hematopoietic stem cell transplants are at increased risk of mortality $[18,26,78]$. Transplant physicians and nephrologists should work together starting from the time prior to transplant to monitor these patients closely. More accurate measures of kidney function are needed, and baseline and follow-up iohexol or iothalamate studies to measure GFR may be indicated to identify patients with underlying CKD prior to transplant and to allow early identification and intervention in patients with mild changes in GFR posttransplant. New markers to estimate GFR, such as cystatin $\mathrm{C}$, may be more informative in certain patient populations than is serum creatinine. Cystatin $\mathrm{C}$ is a cysteine protease inhibitor expressed by all nucleated cells and is freely filtered by the glomerulus. Serum cystatin C correlates well with measured GFR and more accurately measures kidney function than does serum creatinine in the elderly, cancer patients, diabetics, and renal transplant recipients [79-83]. Normal ranges for cystatin $\mathrm{C}$ have been validated in children. The normal reference range for children older than 1 year is $0.7-1.38 \mathrm{mg} / \mathrm{dl}$ [84]. An equation to estimate GFR based on cystatin $\mathrm{C}$ levels in children has also been created: $\log (\mathrm{GFR})=1.962+$ [1.123* $\log (1 /$ cystatin C)] [85]. Urinalyses including a microalbumin to creatinine ratio should also be part of the pretransplant workup, and urinalyses should be monitored closely following transplant.

Animal models of HSCT, and specifically of radiationinduced HUS, offer potential interventions for patients with HUS after HSCT. Angiotensin-converting enzyme inhibitors (ACEI) have been used in rodent models of HSCTrelated renal injury. The use of captopril or enalapril at the time of TBI in these animals resulted in less azotemia, lower blood pressures, decreased proteinuria, and long-term preservation of renal function [86]. ACEI and angiotensin receptor blockers (ARBs) also help reduce inflammation and inflammatory markers and reduce circulating levels of TGF- $\beta 1$ in patients after transplant [87-90]. These agents have also been shown to slow CKD progression and decrease proteinuria in patients with renal disease from various causes [91, 92].

Hypertension management early after transplant is important to prevent CKD development and progression to ESRD in certain transplant populations. ARBs and ACEIs have been shown to be effective and safe in managing hypertension in cardiac transplant patients [93], and ACEIs have been shown to stabilize renal function over 2 years of follow-up [94]. These drugs should be considered as first-line agents to manage hypertension in patients after transplant. In addition, hyperlipidemia management may be important to prevent CKD after transplant. In a study of adult patients undergoing a cardiac transplant, statin use was associated with a decreased risk of development of CKD after transplant [78]. The difficult decision is when to intervene (Fig. 1). Should patients be started on these medications prior to transplant, at the first signs of hypertension and microalbuminuria, or at some set time point after transplant to help protect their kidneys? These decisions need to be made on an individual basis and will vary based on the type of transplant. Frequent 


\section{When to intervene?}

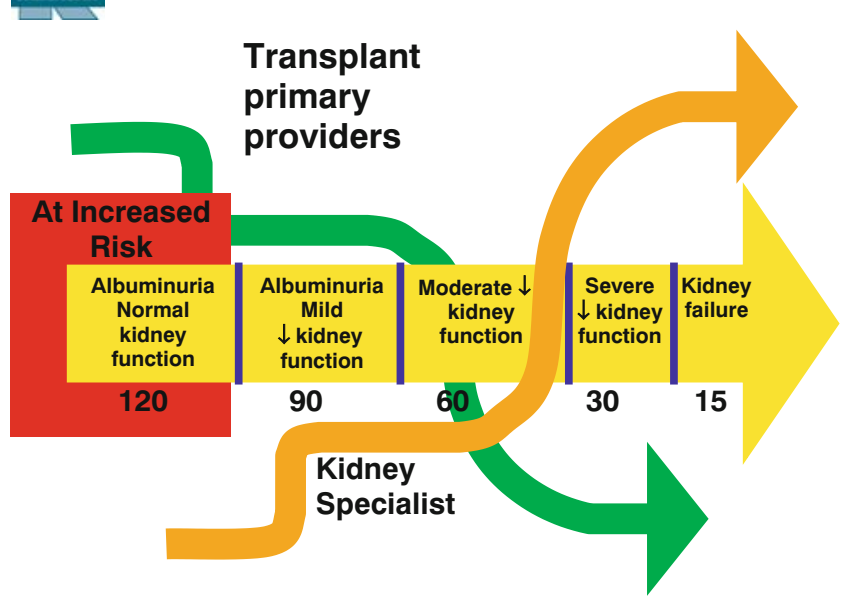

Fig. 1 Timing of intervention. Bold numbers are estimated glomerular filtration rate based on the Kidney Disease Outcomes Quality Initiative (KDOQI) guidelines. Adapted with permission from [102]

discussions between the transplant physician and nephrologist are required to optimize the management of patients with CKD after transplant.

In addition to the above medications, immunosuppression adjustment is important in managing the CKD that develops after transplant, further supporting the need for close collaboration between transplant physicians and nephrologists. In two reported series of lung transplant recipients, sirolimus was used to decrease and eventually stop calcineurin inhibitors in patients with CKD after transplant. Patients had a sustained improvement in kidney function as reflected by a decrease in serum creatinine for 1-12 months [95, 96]. However, prior to changes in immunosuppression, a kidney biopsy may be indicated to define the etiology of the kidney injury and better tailor therapy to prevent or slow disease progression.

Management of patients with ESRD after transplant include the use of peritoneal and/or hemodialysis. Caring for these patients also involves management of complications associated with ESRD, which include anemia, bone disease, hypertension, and metabolic abnormalities. There have been case series of patients undergoing renal transplantation successfully after cardiac, liver or HSCT; renal transplantation is a viable option for patients with ESRD after transplant and can improve outcomes [19, 97-101].

\section{Questions}

(Answers appear following the reference list)

1. Which of the following are risk factors for developing CKD after cardiac, liver, and HSCT?

a. Calcineurin inhibitors

b. Total body irradiation
c. Acute renal failure
d. Hypertension

2. All of the following are manifestations of CKD seen in patients after HSCT except:
a. Nephrotic syndrome
b. Acute glomerulonephritis
c. Thrombotic microangiopathy
d. GVHD-related CKD

3. What pretransplant factors increase the risk of CKD in pediatric cardiac and liver transplant patients?
a. Preexisting renal disease
b. Race
c. Pretransplant diabetes
d. All of the above

4. Management of pediatric patients who develop CKD after transplant should include all of the following except:
a. Reducing exposure to calcineurin inhibitors
b. ACEI and/or ARB
c. Calcium-channel blockers
d. Statin use

5. What is the most common cause for developing TMA after transplant in patients receiving a heart, liver, or stem cell transplant?
a. Graft-versus-host disease
b. Total body irradiation
c. Calcineurin inhibitor use
d. Diabetes

\section{References}

1. Campbell KM, Yazigi N, Ryckman FC, Alonso M, Tiao G, Balistreri WF, Atherton H, Bucuvalas JC (2006) High prevalence of renal dysfunction in long-term survivors after pediatric liver transplantation. J Pediatr 148:475-480

2. Mention K, Lahoche-Manucci A, Bonnevalle M, Pruvot FR, Declerck N, Foulard M, Gottrand F (2005) Renal function outcome in pediatric liver transplant recipients. Pediatr Transplant 9:201-207

3. Berg UB, Ericzon BG, Nemeth A (2001) Renal function before and long after liver transplantation in children. Transplantation 72:631-637

4. Kalicinski P, Szymczak M, Smirska E, Pawlowska J, Teisseyre M, Kaminski A, Broniszczak D, Lembas A, Klimaszewski J (2005) Longitudinal study of renal function in pediatric liver transplant recipients. Ann Transplant 10:53-58

5. Kim DY, Lim C, Parasuraman R, Raoufi M, Yoshida A, Arenas J, Denny J, Malinzak L, Almarastani M, Moonka D, Brown K, Sherbondy M, Gordon S, Abouljoud M (2006) Renal disease burden following liver transplantation. Transplant Proc 38:36633665 
6. Boucek MM, Waltz DA, Edwards LB, Taylor DO, Keck BM, Trulock EP, Hertz MI (2006) Registry of the International Society for Heart and Lung Transplantation: ninth official pediatric heart transplantation report-2006. J Heart Lung Transplant 25:893-903

7. Ross M, Kouretas P, Gamberg P, Miller J, Burge M, Reitz B, Robbins R, Chin C, Bernstein D (2006) Ten- and 20-year survivors of pediatric orthotopic heart transplantation. J Heart Lung Transplant 25:261-270

8. Smith RR, Wray J, Khaghani A, Yacoub M (2005) Ten year survival after paediatric heart transplantation: a single centre experience. Eur J Cardiothorac Surg 27:790-794

9. Phan V, West LJ, Stephens D, Hebert D (2003) Renal complications following heart transplantation in children: a single-center study. Am J Transplant 3:214-218

10. Sigfusson G, Fricker FJ, Bernstein D, Addonizio LJ, Baum D, Hsu DT, Chin C, Miller SA, Boyle GJ, Miller J, Lawrence KS, Douglas JF, Griffith BP, Reitz BA, Michler RE, Rose EA, Webber SA (1997) Long-term survivors of pediatric heart transplantation: a multicenter report of sixty-eight children who have survived longer than five years. J Pediatr 130:862-871

11. Ishani A, Erturk S, Hertz MI, Matas AJ, Savik K, Rosenberg ME (2002) Predictors of renal function following lung or heart-lung transplantation. Kidney Int 61:2228-2234

12. Canales M, Youssef P, Spong R, Ishani A, Savik K, Hertz M, Ibrahim HN (2006) Predictors of chronic kidney disease in longterm survivors of lung and heart-lung transplantation. Am J Transplant 6:2157-2163

13. Kunst H, Thompson D, Hodson M (2004) Hypertension as a marker for later development of end-stage renal failure after lung and heart-lung transplantation: a cohort study. J Heart Lung Transplant 23:1182-1188

14. Tarbell NJ, Guinan EC, Niemeyer C, Mauch P, Sallan SE, Weinstein HJ (1988) Late onset of renal dysfunction in survivors of bone marrow transplantation. Int J Radiat Oncol Biol Phys 15:99-104

15. Cohen EP, Lawton CA, Moulder JE (1995) Bone marrow transplant nephropathy: radiation nephritis revisited. Nephron $70: 217-222$

16. Weiss AS, Sandmaier BM, Storer B, Storb R, McSweeney PA, Parikh CR (2006) Chronic kidney disease following nonmyeloablative hematopoietic cell transplantation. Am J Transplant 6:89-94

17. Hingorani S, Guthrie KA, Schoch G, Weiss NS, McDonald GB (2007) Chronic kidney disease in long-term survivors of hematopoietic cell transplant. Bone Marrow Transplant 39:223-229

18. Cohen EP, Piering WF, Kabler-Babbitt C, Moulder JE (1998) End-stage renal disease (ESRD) after bone marrow transplantation: poor survival compared to other causes of ESRD. Nephron 79:408-412

19. Thomas SE, Hutchinson RJ, DebRoy M, Magee JC (2004) Successful renal transplantation following prior bone marrow transplantation in pediatric patients. Pediatr Transplant 8:507-512

20. Ojo AO, Held PJ, Port FK, Wolfe RA, Leichtman AB, Young EW, Arndorfer J, Christensen L, Merion RM (2003) Chronic renal failure after transplantation of a nonrenal organ. $\mathrm{N}$ Engl $\mathrm{J}$ Med 349:931-940

21. Chin SE, Axelsen RA, Crawford DH, Endre ZH, Lynch SV, Balderson GA, Strong RW, Shepherd RW, Burke JR, Fleming SJ (1992) Glomerular abnormalities in children undergoing orthotopic liver transplantation. Pediatr Nephrol 6:407-411

22. Querfeld U, Boechat IM, Vargas J, Hawkins R, Berquist B, Kangarloo H, Busuttil RW, Fine RN (1991) Renal ultrasound abnormalities in children with end-stage liver disease-reversal by liver transplantation. Pediatr Nephrol 5:18-21

23. Velidedeoglu E, Bloom RD, Crawford MD, Desai NM, Campos L, Abt PL, Markmann JW, Mange KC, Olthoff KM, Shaked A,
Markmann JF (2004) Early kidney dysfunction post liver transplantation predicts late chronic kidney disease. Transplantation 77:553-556

24. Fisher NC, Nightingale PG, Gunson BK, Lipkin GW, Neuberger JM (1998) Chronic renal failure following liver transplantation: a retrospective analysis. Transplantation 66:59-66

25. Pillebout E, Nochy D, Hill G, Conti F, Antoine C, Calmus Y, Glotz D (2005) Renal histopathological lesions after orthotopic liver transplantation (OLT). Am J Transplant 5:1120-1129

26. Gonwa TA, Mai ML, Melton LB, Hays SR, Goldstein RM, Levy MF, Klintmalm GB (2001) End-stage renal disease (ESRD) after orthotopic liver transplantation (OLTX) using calcineurin-based immunotherapy: risk of development and treatment. Transplantation 72:1934-1939

27. Atkinson K, Biggs JC, Hayes J, Ralston M, Dodds AJ, Concannon AJ, Naidoo D (1983) Cyclosporin A associated nephrotoxicity in the first 100 days after allogeneic bone marrow transplantation: three distinct syndromes. Br J Haematol 54:59-67

28. Myers BD, Sibley R, Newton L, Tomlanovich SJ, Boshkos C, Stinson E, Luetscher JA, Whitney DJ, Krasny D, Coplon NS, Perlroth MG (1988) The long-term course of cyclosporineassociated chronic nephropathy. Kidney Int 33:590-600

29. Myers BD, Ross J, Newton L, Luetscher J, Perlroth M (1984) Cyclosporine-associated chronic nephropathy. N Engl J Med 311:699-705

30. McDiarmid SV (1996) Renal function in pediatric liver transplant patients. Kidney Int Suppl 53:S77-S84

31. van de Wetering J, Weimar CH, Balk AH, Roodnat JI, Holweg CT, Baan CC, van Domburg RT, Weimar W (2006) The impact of transforming growth factor-beta1 gene polymorphism on endstage renal failure after heart transplantation. Transplantation 82:1744-1748

32. Ferraris JR, Duca P, Prigoshin N, Tambutti ML, Boldrini G, Cardoni RL, D'Agostino D (2004) Mycophenolate mofetil and reduced doses of cyclosporine in pediatric liver transplantation with chronic renal dysfunction: changes in the immune responses. Pediatr Transplant 8:454-459

33. Laine J, Krogerus L, Fyhrquist F, Jalanko H, Ronnholm K, Holmberg C (1994) Renal function and histopathologic changes in children after liver transplantation. J Pediatr 125:863-869

34. Vester U, Kranz B, Nadalin S, Paul A, Becker J, Hoyer PF (2005) Sirolimus rescue of renal failure in children after combined liver-kidney transplantation. Pediatr Nephrol 20:686689

35. Al Aly Z, Abbas S, Moore E, Diallo O, Hauptman PJ, Bastani B (2005) The natural history of renal function following orthotopic heart transplant. Clin Transplant 19:683-689

36. Veillon S, Caillard S, Epailly E, Eisenmann B, Hannedouche T, Moulin B (2002) Chronic renal failure after cardiac transplantation: predictive factors and influence on mortality-results of a monocenter study in 141 patients. Transplant Proc 34:2819-2820

37. Lee CK, Christensen LL, Magee JC, Ojo AO, Harmon WE, Bridges ND (2007) Pre-transplant risk factors for chronic renal dysfunction after pediatric heart transplantation: a 10-year national cohort study. J Heart Lung Transplant 26:458-465

38. Lindelow B, Bergh CH, Herlitz H, Waagstein F (2000) Predictors and evolution of renal function during 9 years following heart transplantation. J Am Soc Nephrol 11:951-957

39. Esposito C, Semeraro L, Bellotti N, Fasoli G, Fornoni A, Rampino T, Klersy C, Campana C, Gavazzi A, Vigano M, Dal Canton A (2000) Risk factors for chronic renal dysfunction in cardiac allograft recipients. Nephron 84:21-28

40. Hendawy A, Pouteil-Noble C, Villar E, Boissonnat P, Sebbag L (2005) Chronic renal failure and end-stage renal disease are associated with a high rate of mortality after heart transplantation. Transplant Proc 37:1352-1354 
41. Laine J, Jalanko H, Leijala M, Sairanen H, Holmberg C (1997) Kidney function in cyclosporine-treated pediatric heart transplant recipients. J Heart Lung Transplant 16:1217-1224

42. Hornung TS, de Goede CG, O'Brien C, Moghal NE, Dark JH, O'Sullivan F (2001) Renal function after pediatric cardiac transplantation: the effect of early cyclosporin dosage. Pediatrics 107:1346-1350

43. Rubel JR, Milford EL, McKay DB, Jarcho JA (2004) Renal insufficiency and end-stage renal disease in the heart transplant population. J Heart Lung Transplant 23:289-300

44. Boyer O, Le Bidois J, Dechaux M, Gubler MC, Niaudet P (2005) Improvement of renal function in pediatric heart transplant recipients treated with low-dose calcineurin inhibitor and mycophenolate mofetil. Transplantation 79:1405-1410

45. Asante-Korang A, Boyle GJ, Webber SA, Miller SA, Fricker FJ (1996) Experience of FK506 immune suppression in pediatric heart transplantation: a study of long-term adverse effects. J Heart Lung Transplant 15:415-422

46. Parimon T, Au DH, Martin PJ, Chien JW (2006) A risk score for mortality after allogeneic hematopoietic cell transplantation. Ann Intern Med 144:407-414

47. Moake JL (2002) Thrombotic microangiopathies. N Engl J Med 347:589-600

48. Antignac C, Gubler MC, Leverger G, Broyer M, Habib R (1989) Delayed renal failure with extensive mesangiolysis following bone marrow transplantation. Kidney Int 35:1336-1344

49. Lawton CA, Cohen EP, Murray KJ, Derus SW, Casper JT, Drobyski WR, Horowitz MM, Moulder JE (1997) Long-term results of selective renal shielding in patients undergoing total body irradiation in preparation for bone marrow transplantation. Bone Marrow Transplant 20:1069-1074

50. Pettitt AR, Clark RE (1994) Thrombotic microangiopathy following bone marrow transplantation. Bone Marrow Transplant 14:495-504

51. Schriber JR, Herzig GP (1997) Transplantation-associated thrombotic thrombocytopenic purpura and hemolytic uremic syndrome. Semin Hematol 34:126-133

52. Zeigler ZR, Rosenfeld CS, Andrews DF 3rd, Nemunaitis J, Raymond JM, Shadduck RK, Kramer RE, Gryn JF, Rintels PB, Besa EC, George JN (1996) Plasma von Willebrand Factor Antigen (vWF:AG) and thrombomodulin (TM) levels in Adult Thrombotic Thrombocytopenic Purpura/Hemolytic Uremic Syndromes (TTP/ HUS) and bone marrow transplant-associated thrombotic microangiopathy (BMT-TM). Am J Hematol 53:213-220

53. Chappell ME, Keeling DM, Prentice HG, Sweny P (1988) Haemolytic uraemic syndrome after bone marrow transplantation: an adverse effect of total body irradiation. Bone Marrow Transplant 3:339-347

54. Sarkodee-Adoo C, Sotirescu D, Sensenbrenner L, Rapoport AP, Cottler-Fox M, Tricot G, Ruehle K, Meisenberg B (2003) Thrombotic microangiopathy in blood and marrow transplant patients receiving tacrolimus or cyclosporine A. Transfusion 43:78-84

55. Uderzo C, Fumagalli M, De Lorenzo P, Busca A, Vassallo E, Bonanomi S, Lanino E, Dini G, Varotto S, Messina C, Miniero R, Valsecchi MG, Balduzzi A (2000) Impact of thrombotic thrombocytopenic purpura on leukemic children undergoing bone marrow transplantation. Bone Marrow Transplant 26:1005-1009

56. Fuge R, Bird JM, Fraser A, Hart D, Hunt L, Cornish JM, Goulden N, Oakhill A, Pamphilon DH, Steward CG, Marks DI (2001) The clinical features, risk factors and outcome of thrombotic thrombocytopenic purpura occurring after bone marrow transplantation. Br J Haematol 113:58-64

57. Hahn T, Alam AR, Lawrence D, Ford L, Baer MR, Bambach B, Bernstein ZP, Czuczman MS, Silva J, Slack JL, Wetzler M, Becker J,
McCarthy PL Jr (2004) Thrombotic microangiopathy after allogeneic blood and marrow transplantation is associated with doseintensive myeloablative conditioning regimens, unrelated donor, and methylprednisolone T-cell depletion. Transplantation 78:1515-1522

58. Daly AS, Hasegawa WS, Lipton JH, Messner HA, Kiss TL (2002) Transplantation-associated thrombotic microangiopathy is associated with transplantation from unrelated donors, acute graft-versus-host disease and venoocclusive disease of the liver. Transfus Apher Sci 27:3-12

59. Uderzo C, Bonanomi S, Busca A, Renoldi M, Ferrari P, Iacobelli M, Morreale G, Lanino E, Annaloro C, Volpe AD, Alessandrino P, Longoni D, Locatelli F, Sangalli H, Rovelli A (2006) Risk factors and severe outcome in thrombotic microangiopathy after allogeneic hematopoietic stem cell transplantation. Transplantation 82:638-644

60. Van Why SK, Friedman AL, Wei LJ, Hong R (1991) Renal insufficiency after bone marrow transplantation in children. Bone Marrow Transplant 7:383-388

61. Lonnerholm G, Carlson K, Bratteby LE, Backlund L, Hagberg H, Rikner G, Smedmyr B, Oberg G, Simonsson B (1991) Renal function after autologous bone marrow transplantation. Bone Marrow Transplant 8:129-134

62. Kist-van Holthe JE, Goedvolk CA, Brand R, van Weel MH, Bredius RG, van Oostayen JA, Vossen JM, van der Heijden BJ (2002) Prospective study of renal insufficiency after bone marrow transplantation. Pediatr Nephrol 17:1032-1037

63. Gronroos MH, Bolme P, Winiarski J, Berg UB (2007) Long-term renal function following bone marrow transplantation. Bone Marrow Transplant 39:717-723

64. Berg U, Bolme P (1989) Renal function in children following bone marrow transplantation. Transplant Proc 21:3092-3094

65. Levey AS, Bosch JP, Lewis JB, Greene T, Rogers N, Roth D (1999) A more accurate method to estimate glomerular filtration rate from serum creatinine: a new prediction equation. Modification of Diet in Renal Disease Study Group. Ann Intern Med 130:461-470

66. Fliser D, Franek E, Joest M, Block S, Mutschler E, Ritz E (1997) Renal function in the elderly: impact of hypertension and cardiac function. Kidney Int 51:1196-1204

67. Patzer L, Ringelmann F, Kentouche K, Fuchs D, Zintl F, Brandis M, Zimmerhackl LB, Misselwitz J (2001) Renal function in long-term survivors of stem cell transplantation in childhood. A prospective trial. Bone Marrow Transplant 27:319-327

68. Kist-van Holthe J, van Zwet J, Brand R, van Weel M, Vossen J, van der Heijden A (1998) Bone marrow transplantation in children: consequences for renal function shortly after and 1 year post-BMT. Bone Marrow Transplantation 22:559-564

69. Frisk P, Bratteby LE, Carlson K, Lonnerholm G (2002) Renal function after autologous bone marrow transplantation in children: a long-term prospective study. Bone Marrow Transplant 29:129-136

70. Rao PS (2005) Nephrotic syndrome in patients with peripheral blood stem cell transplant. Am J Kidney Dis 45:780-785

71. Brukamp K, Doyle AM, Bloom RD, Bunin N, Tomaszewski JE, Cizman B (2006) Nephrotic syndrome after hematopoietic cell transplantation: do glomerular lesions represent renal graftversus-host disease. Clin J Am Soc Nephrol 1:685-694

72. Chan GS, Lam MF, Au WY, Tse KC, Chan TM, Lai KN, Chan KW (2004) IgA nephropathy complicating graft-versus-host disease, another nephropathy causing nephrotic syndrome after bone marrow transplantation. Histopathology 45:648-651

73. Oliveira JS, Bahia D, Franco M, Balda C, Stella S, Kerbauy J (1999) Nephrotic syndrome as a clinical manifestation of graft-versus-host disease (GVHD) in a marrow transplant recipient after cyclosporine withdrawal. Bone Marrow Transplant 23:99-101

74. Suehiro T, Masutani K, Yokoyama M, Tokumoto M, Tsuruya K, Fukuda K, Kanai H, Katafuchi R, Nagatoshi Y, Hirakata H 
(2002) Diffuse proliferative glomerulonephritis after bone marrow transplantation. Clin Nephrol 58:231-237

75. Nouri-Majelan N, Sanadgol H, Ghafari A, Rahimian M, Najafi F, Mortazavizadeh M, Moghaddasi S (2005) Antineutrophil cytoplasmic antibody-associated glomerulonephritis in chronic graftversus-host disease after allogenic hematopoietic stem cell transplantation. Transplant Proc 37:3213-3215

76. Chien YH, Lin KH, Lee TY, Lu MY, Tsau YK (2000) Nephrotic syndrome in a bone marrow transplant recipient without chronic graft-versus-host disease. J Formos Med Assoc 99:503-506

77. Reddy P, Johnson K, Uberti JP, Reynolds C, Silver S, Ayash L, Braun TM, Ratanatharathorn V (2006) Nephrotic syndrome associated with chronic graft-versus-host disease after allogeneic hematopoietic stem cell transplantation. Bone Marrow Transplant 38:351-357

78. Lubitz SA, Pinney S, Wisnivesky JP, Gass A, Baran DA (2007) Statin therapy associated with a reduced risk of chronic renal failure after cardiac transplantation. J Heart Lung Transplant $26: 264-272$

79. Dharnidharka VR, Kwon C, Stevens G (2002) Serum cystatin C is superior to serum creatinine as a marker of kidney function: a meta-analysis. Am J Kidney Dis 40:221-226

80. Al-Tonbary YA, Hammad AM, Zaghloul HM, El-Sayed HE, Abu-Hashem E (2004) Pretreatment cystatin C in children with malignancy: can it predict chemotherapy-induced glomerular filtration rate reduction during the induction phase. J Pediatr Hematol Oncol 26:336-341

81. Seronie-Vivien S, Toullec S, Malard L, Thomas F, Durrand V, Chatelut E (2006) Contribution of the MDRD equation and of cystatin $\mathrm{C}$ for renal function estimates in cancer patients. Med Oncol 23:63-73

82. Ross EA, Wilkinson A, Hawkins RA, Danovitch GM (1987) The plasma creatinine concentration is not an accurate reflection of the glomerular filtration rate in stable renal transplant patients receiving cyclosporine. Am J Kidney Dis 10:113-117

83. Visvardis G, Griveas I, Zilidou R, Papadopoulou D, Mitsopoulos E, Kyriklidou P, Manou E, Ginikopoulou E, Meimaridou D, Pavlitou A, Sakellariou G (2004) Glomerular filtration rate estimation in renal transplant patients based on serum cystatin-C levels: comparison with other markers of glomerular filtration rate. Transplant Proc 36:1757-1759

84. Bokenkamp A, Domanetzki M, Zinck R, Schumann G, Byrd D, Brodehl J (1998) Cystatin C-a new marker of glomerular filtration rate in children independent of age and height. Pediatrics 101:875-881

85. Filler G, Lepage N (2003) Should the Schwartz formula for estimation of GFR be replaced by cystatin $\mathrm{C}$ formula. Pediatr Nephrol 18:981-985

86. Cohen EP (2000) Radiation nephropathy after bone marrow transplantation. Kidney Int 58:903-918

87. Lopez Santi RG, Valeff EC, Duymovich CR, Mazziotta D, Mijailovsky NE, Filippa GC, Maltez R, Hernandez VA, Monroy AG, Borzi JG, Acheme RA, Etchegoyen MC (2005) Effects of an angiotensin-converting enzyme inhibitor (ramipril) on inflammatory markers in secondary prevention patients: RAICES Study. Coron Artery Dis 16:423-429

88. Dagenais NJ, Jamali F (2005) Protective effects of angiotensin II interruption: evidence for antiinflammatory actions. Pharmacotherapy 25:1213-1229

89. Lin J, Valeri AM, Markowitz GS, D'Agati VD, Cohen DJ, Radhakrishnan J (2002) Angiotensin converting enzyme inhibition in chronic allograft nephropathy. Transplantation 73:783-788

90. Hetzel GR, Hermsen D, Hohlfeld T, Rettich A, Ozcan F, Fussholler A, Grabensee B, Plum J (2002) Effects of candesartan and perindopril on renal function, TGF-betal plasma levels and excretion of prostaglandins in stable renal allograft recipients. Clin Nephrol 57:296-302

91. Maschio G, Alberti D, Janin G, Locatelli F, Mann JF, Motolese M, Ponticelli C, Ritz E, Zucchelli P (1996) Effect of the angiotensinconverting-enzyme inhibitor benazepril on the progression of chronic renal insufficiency. The Angiotensin-Converting-Enzyme Inhibition in Progressive Renal Insufficiency Study Group. N Engl J Med 334:939-945

92. Sica DA, Gehr TW, Fernandez A (2000) Risk-benefit ratio of angiotensin antagonists versus ACE inhibitors in end-stage renal disease. Drug Saf 22:350-360

93. Brozena SC, Johnson MR, Ventura H, Hobbs R, Miller L, Olivari MT, Clemson B, Bourge R, Quigg R, Mills RM Jr, Naftel D (1996) Effectiveness and safety of diltiazem or lisinopril in treatment of hypertension after heart transplantation. Results of a prospective, randomized multicenter trail. J Am Coll Cardiol 27:1707-1712

94. Elliott WJ, Murphy MB, Karp R (1991) Long-term preservation of renal function in hypertensive heart transplant recipients treated with enalapril and a diuretic. J Heart Lung Transplant 10:373-379

95. Snell GI, Levvey B, Chin W, Richardson M, Kotsimbos T, Whitford HM, Williams TJ (2001) Sirolimus (rapamycin) allows renal recovery in lung and heart transplant recipients with chronic renal impairment. J Heart Lung Transplant 20:163-164

96. Venuta F, De Giacomo T, Rendina EA, Quattrucci S, Mercadante E, Cimino G, Ibrahim M, Diso D, Bachetoni A, Coloni GF (2004) Recovery of chronic renal impairment with sirolimus after lung transplantation. Ann Thorac Surg 78:1940-1943

97. Butcher JA, Hariharan S, Adams MB, Johnson CP, Roza AM, Cohen EP (1999) Renal transplantation for end-stage renal disease following bone marrow transplantation: a report of six cases, with and without immunosuppression. Clin Transplant 13: 330-335

98. Hamawi K, De Magalhaes-Silverman M, Bertolatus JA (2003) Outcomes of renal transplantation following bone marrow transplantation. Am J Transplant 3:301-305

99. Kuo PC, Luikart H, Busse-Henry S, Hunt SA, Valantine HA, Stinson EB, Oyer PE, Scandling JD, Alfrey EJ, Dafoe DC (1995) Clinical outcome of interval cadaveric renal transplantation in cardiac allograft recipients. Clin Transplant 9:92-97

100. Frimat L, Villemot JP, Cormier L, Cao-Huu T, Renoult E, Hestin D, Dopff C, Mattei S, Hubert J, Kessler M (1998) Treatment of end-stage renal failure after heart transplantation. Nephrol Dial Transplant 13:2905-2908

101. Molmenti EP, Jain AB, Shapiro R, Scantlebury V, Lee R, Totsuka E, Flohr J, Rakela J, Fung JJ (2001) Kidney transplantation for end-stage renal failure in liver transplant recipients with hepatitis C viral infection. Transplantation 71:267-271

102. National Kidney Foundation (2002) K/DOQI clinical practice guidelines for chronic kidney disease: evaluation, classification, and stratification. Am J Kidney Dis 39(Suppl 1):S1-S266

\section{Answers:}

1. a and c

2. $\mathrm{b}$

3. d

4. c

5. c 